\title{
Effect of Landfill Leachate on Brassica chinensis Dry Matter Weight and Iron Concentration
}

\author{
Reza Farzinebrahimi, R. M. Taha, K. A. Rashid, M. Fadaienasab, and M. K. Yusoff
}

\begin{abstract}
To compare the dry matter yield and iron uptake of Brassica chinensis, soil iron content at 15, 23, 31, 39 days after transplanting the seedlings of Brassica chinensis with respect to different concentration of landfill leachate concentrations at $0,33.3,50$ and $100 \%$ application on soil were measured. Treated $B$. chinensis with $100 \%, 50 \%$ and $33.3 \%$ leachates increased in dry matter yield by $59.2 \%, 66.4 \%$ and $95.7 \%$ respectively compared to control irrigated water. The highest and lowest iron uptake by $B$. chinensis observed at fifteen and twenty-three days after transplanting respectively. The iron concentrated in soil showed significant differences only at twenty tree days after transplanting the seedlings of $B$. chinensis to $100,0,33.3$ and $50 \%$ of landfill leachate concentrations respectively.
\end{abstract}

Index Terms-Brassica chinensis, iron, landfill leachate.

\section{INTRODUCTION}

Landfill is one of the widely used disposal method of municipal solid wastes due to its low management cost and provides a good service if properly implemented [1]. The most apparent contamination cases are ground water contamination [2] and soil contamination [3]. According to [4], the composition of landfill leachate is variable and contains high concentration of heavy metals. However, many literatures available on some of the metal's concentration in soil fall off with distance from roads [5]-[7], industrial center [8], [9] and wasteland [10]-[12].

Various studies have been carried out in Europe regarding the leachate for agricultural utilization and their management practices such as decontamination of leachate on plant-soil system. However, these data cannot wholly be applied locally, due to variation in metal content in leachate source, soil properties, climate condition and others. A few researches have been conducted to study the contamination potential of plants by under tropical climate condition landfill leachate. Furthermore, a better understanding of metals interaction with soil and plant is necessary to enable management of landfill leachate effectively. Therefore, it is essential to study the effect if landfill leachate to plant growth and metals uptake, and soil metals content, under Malaysia tropical climate condition.

Pak Choi or commonly known as 'bok choy' (Brassica

Manuscript received April 1, 2013; revised June 3, 2013.

Reza Farzinebrahimi, R. M. Taha, and K. A. Rashid are with Institute of Biological Sciences, University of Malaya, 50603 Kuala Lumpur, Malaysia (email: rfebrahimi@siswa.um.edu.my).

M. Fadaienasab is with Chemistry department, University of Malaya, 50603 Kuala Lumpur, Malaysia.

M. K. Yusoff is with Faculty of Agriculture, University of Putra Malaysia, Serdang, Malaysia. chinensis) is a member of the Mustard family. Pak Choi and its variations are amongst the most popular vegetables used in Chinese cooking in Hong Kong and parts of Southern China, Malaysia is now commonplace in European cooking. The broad green leaves, which taper to white stalks, are crisp and crunchy. Pak Choi leaves are soft and succulent, with crunchy white or green stalks and young sweet flavored flower shoots. The whole plant is edible. The slight mustard flavor of Pak Choi makes it a delightful. In China, the coarser leaves are often pickled. The Cantonese name is bok choy or pak choi and the Mandarin name is bai cai. The name means white vegetable in Chinese [7].

A greenhouse experimental was conducted in this study by utilizing this leafy vegetable, to monitor the level of leachate iron uptake and the vegetable response to leachate exposure.

\section{OBJECTIVE}

To compare the dry matter yield and iron uptake of vegetables, soil iron content at four growth stages with respect to different concentration of landfill leachates application on soil.

The result of this study will provide information of interaction between iron uptake by plants and soil iron content treated with landfill leachate. A better understanding of plant growth and metal accumulation interaction with leachate application is necessary for a proper landfill leachate management.

\section{Methodology}

\section{A. Field Experiment}

A randomized complete block design (RCBD) was selected for this study, with four replications of vegetables. There were three sources of variability in a RCBD design: treatment, replication (or block), and experimental error. It was done to maximize the variability among blocks (due to the location of greenhouse might cause the possibility of the block receiving different natural sunlight density in morning and afternoon) and minimize variability within each blocks.

A 3:2:1 mixture of top soil, peat soil and sand was used as growth medium. Seeds of Brassica chinensis were planted in $8^{*} 15 \mathrm{~cm}$ poly bags containing of soil mixture. The data of iron content in soil and vegetable and dry matter weight of vegetable were collected at 8 days intervals for four times, starting from 15 to 39 days after transplanting.

Some of the preliminary chemical and physical properties of soil (texture, organic carbon, $\mathrm{pH}$, cation exchange capacity and selected heavy metals) and leachate (such as 
$\mathrm{pH}$, conductivity and selected heavy metals) were determined. Leachate was obtained from the municipal landfill that was located at Taman Berigin.

Leachate was collected from collection trench after the aeration pond on $17^{\text {th }}$ January 2012. Leachate was applied on the soil in the four treatments from with untreated leachate to tap water ratio of 1:0 (100\% leachate), 1:1 (50\% leachate), 1:2 (33\% leachate) and $0: 1 \quad(0 \%$ leachate). Leachate was applied in a single application with the volume of 1.5 Liter to saturate the soil in the poly bag. Volume of leachate applied depends on the total porosity of soil in poly bag.

Pak choi was watered 2-3 times daily in the morning and evening. The volume of water applied was differed according to the water requirement at different growth stage. The volume of water applied daily was recorded. Insecticides were used when the condition was needed at the recommended rate. Weeds in the pots and the surrounding area were controlled by hand weeding. Each vegetable received $0.50 \mathrm{~g}$ amount of fertilizer $\left(15 \%\right.$ total $\mathrm{N}, 15 \% \mathrm{P}_{2} \mathrm{O}_{5}$, $\left.15 \% \mathrm{~K}_{2} \mathrm{O}\right)$ to promote enough growth for tissue sampling.

Soil $\mathrm{pH}$ was determined by $\mathrm{PH}-\mathrm{H}_{2} \mathrm{O}(1: 2.5)$ method and soil cation exchange capacity was determined by ammonium acetate method, using sodium as index ion.

Texture unit code 1067 from LaMotte Company was used for soil texture. The base of this test is soil separate into sand, silt, and clay. The amount of time required for the soil particles of various sizes to settle in the soil separation tubes forms the basis for this test. From the amount of material collected in each tube, it is possible to determine the approximate percentage of each fraction as represented in the original soil sample [13].

\section{B. Dry Matter Weight}

The whole vegetable was harvested, transported to laboratory as quickly as possible. The samples were cleaned with $0.2 \%$ Teepol detergent and rinsed with deionizes water to decontaminate tissue surface according to [14]. The samples were oven dried $\left(75^{\circ} \mathrm{C}\right.$ for 48 hours) to determine dry weight. The initial drying is to deactivate rapidly all plant enzymes, thereby minimizing respiratory weight losses and biochemical changes and to remove all water from the tissue.

\section{Tissue Iron Analysis}

The edible parts were ground, sieved $(1 \mathrm{~mm})$ and stored. The finely ground material was oven dry at $70^{\circ} \mathrm{C}$ for 12 hours immediately before sub samples were weighed for dry ashing, to eliminate moisture which absorbed from atmospheric [15].

The plant tissue analyses were using dry ashing method of [16] and iron was determinated of by flame atomic absorption spectrophotometer model 2380 Perkin Elmer.

\section{Statistical Analysis}

All data were subjected to analysis of variance and means of four treatments compared by Duncan Multiple Range Test (DMRT) at confidence level $95 \%$ by SAS.

\section{Result AND DisCUSSION}

\section{A. Chemical and Physical Properties of Soil Mixture and Landfill Leachate}

Based on (Table I) iron is the most concentrated metal among the detected metals in leachate; therefore, iron was used as an indication for metal accumulation in vegetable and soil in this study.

TABLE I: CHEMICAL AND PHYSICAL PROPERTIES OF SOIL MiXTURE AND LANDFILL LEACHATE [16]

\begin{tabular}{ccc}
\hline \hline Variables & Soil Mixture & Leachate \\
\hline Textures (\%) & 36.66 & \\
Clay & 16.67 & \\
Silt & 46.67 & \\
Sand & 6.55 & \\
Organic Matter (\%) & 40 & 7.97 \\
Porosity & 5.62 & \\
pH & 18.54 & 12.06 \\
C.E.C (m.e/100g soil) & & $\mathrm{mg} / 1$ \\
Conuctivity (mS/cm) & $\mu \mathrm{g} / \mathrm{g}$ (Air Dried Weight Basis) & 6.66 \\
& 48169 & 0.98 \\
\hline Iron & 35.58 & 0.84 \\
Nickel & 15.63 & 0.81 \\
Chromium & 4.33 & 0.3 \\
Lead & 52.33 & 0.2 \\
Zinc & 28.5 & 0.009 \\
Copper & 0.9 & \\
Cadmium & &
\end{tabular}

\section{B. Dry Matter Yield}

Fifteen days after transplanting, there was no significant different in dry matter weight of $B$. chinensis among treatments at 5\% level (Table II). Twenty-three days after transplanting, B. chinensis treated with $50 \%$ and $33.3 \%$ leachates produced higher yield than $0 \%$ leachate treatment (Table II). Thirty-one and thirty-nine days after transplanting, B. chinensis treated with $100 \%, 50 \%$ and $33.3 \%$ leachates produced higher yield than $0 \%$ treatment (Table II). Thirty-nine days after transplanting, B. chinensis treated with $100 \%, 50 \%$ and $33.3 \%$ leachates showed increased in dry matter yield by $59.2 \%, 66.4 \%$ and $95.7 \%$ respectively compared to control irrigated water. Increased weight in $B$. chinensis yield followed by leachate treatment probably due to available nutrient in leachate concentration.

TABLE II: DRY WEIGHT OF B. CHINENSIS UNDER DIFFERENT LEACHATE CONCENTRATION TREATMENTS

\begin{tabular}{ccccc}
\hline \hline & \multicolumn{4}{c}{ Dry Matter Weight, $\mathrm{g}^{\mathrm{a}}$} \\
\hline Leachate Concentration \% & $15 \mathrm{~ns}$ & $23^{*}$ & $31^{*}$ & $39^{* *}$ \\
\hline $\mathbf{1 0 0}$ & 0.6173 & $1.8190 \mathrm{a}$ & $4.4323 \mathrm{a}$ & $5.7888 \mathrm{a}$ \\
$\mathbf{5 0}$ & 0.614 & $2.4923 \mathrm{~b}$ & $5.0618 \mathrm{a}$ & $6.0513 \mathrm{a}$ \\
$\mathbf{3 3 . 3}$ & 0.6708 & $2.6878 \mathrm{~b}$ & $5.0275 \mathrm{a}$ & $7.1155 \mathrm{a}$ \\
$\mathbf{0}$ & 0.4298 & $1.4065 \mathrm{a}$ & $3.1455 \mathrm{~b}$ & $3.6365 \mathrm{~b}$ \\
\hline \hline
\end{tabular}

a: Average of four replications; 15, 2331 and 39 refer to days after transplanting respectively. Means with same letter in the same column are not significantly different at the $5 \%$ level. ns: Not significant.

**: significant at the $1 \%$ levels.

Thirty-nine days after transplanting, B. chinensis treated with higher concentration of leachate showed decrease in yield, but it was not significant at 5\% level (Table II). This 
was probably due to $B$. chinensis treated with leachate suffering from ionic stress without showing any virtual stress symptoms during their growth (Fig. 1).

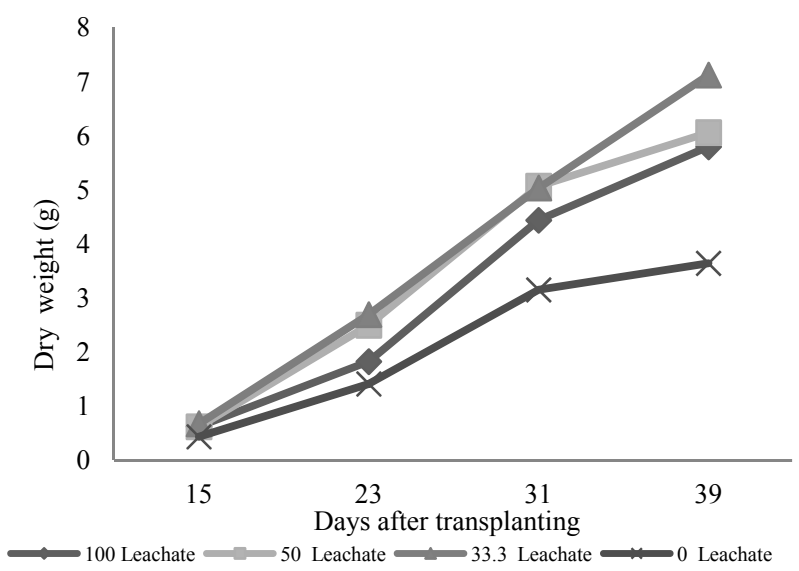

Fig. 1. Effect of different concentration leachates application on dry matter yield of $B$. chinensis.

\section{Iron Accumulation in Soil}

There was no significant different at 5\% level in iron concentration of soil among treatment accept for soil batch 23 days after transplanting (Table III). This indicated that total iron content in leachate added to soil was very low as compared variation of background total iron in soil used as growth medium. This reason made the detection of increasing in soil iron concentration followed by leachate treatment was not successful.

Twenty-three days after transplanting soil treated with $0 \%$, $33.3 \%$ and $100 \%$ leachate had higher iron concentration than soil treated with $50 \%$ leachate (Table III). This was probably due to leach of iron from soil through daily water irrigation and some iron was uptake by $B$. chinensis.

TABLE III: IRON CONCENTRATION IN SOIL UNDER DIFFERENT LEACHATE CONCENTRATION TREATMENTS

\begin{tabular}{ccccc}
\hline \hline & \multicolumn{4}{c}{ Iron Concentration in Soil $(\mathrm{mg} / \mathrm{kga})$} \\
\hline Leachate Concentration $\%$ & $15 \mathrm{~ns}$ & $23^{* *}$ & $31^{\text {ns }}$ & $39^{\text {ns }}$ \\
\hline $\mathbf{1 0 0}$ & 50373 & $50678.6 \mathrm{a}$ & 49328 & 47742 \\
$\mathbf{5 0}$ & 52548 & $47826.3 \mathrm{~b}$ & 50108 & 50183 \\
$\mathbf{3 3 . 3}$ & 50072 & $50091.0 \mathrm{a}$ & 48474 & 50260 \\
$\mathbf{0}$ & 52510 & $51617.9 \mathrm{a}$ & 47249 & 51057 \\
\hline \hline
\end{tabular}

a: Average of four replications; 15, 2331 and 39 refer to days after transplanting respectively. Means with same letter in the same column are not significantly different at the $5 \%$ level.

ns: Not significant.

$*, * *$ : significant at the $5 \%$ and $1 \%$ levels, respectively.

Overall, the soil did not increased in iron content due to leachate treatment but this did not mean that no iron contaminate the soil as $B$. chinensis indicated the iron accumulation trend (Fig. 2).

\section{Iron Uptake by B. Chinensis}

Iron content of $B$. chinensis in four growth stages showed significant differences at 5\% level on 15, 23 and 39 days after transplanting (Table IV). Fifteen days after transplanting, B. chinensis treated with $100 \%$ leachate have lower iron concentration compared to $50 \%$ leachate treatment. This was probably due to the leachate with $\mathrm{pH}$ 7.97 has increased soil $\mathrm{pH}$, which decreased bioavailable iron. Twenty-three days after transplanting, B. chinensis treated with $100 \%$ and $50 \%$ leachate have higher iron concentration than $33.3 \%$ and $0 \%$ leachate treatments. Thirty-nine days after transplanting, B. chinensis treated with $50 \%$ leachate have accumulated higher iron than $33.3 \%$ and $0 \%$ leachate treatments; $100 \%$ leachate have accumulated higher than $0 \%$ leachate treatment (Table IV).

TABLE V: A COMPARISON OF DAYS AFTER TRANSPLANTING ON IRON CONCENTRATION IN $B$. CHINENSIS UNDER DIFFERENT LEACHATE CONCENTRATIONS

\begin{tabular}{ccccc}
\hline \hline \multicolumn{5}{c}{ Iron Concentration in B. Chinensis $\left(\mathrm{mg} / \mathrm{kg}^{\mathrm{a}}\right)$} \\
\hline Days After Transplanting & $100 \%^{\mathrm{ns}}$ & $50 \%{ }^{* *}$ & $31^{\mathrm{ns}}$ & $39^{* *}$ \\
\hline 15 & $136.650 \mathrm{a}$ & $164.950 \mathrm{~b}$ & $136.450 \mathrm{a}$ & $155.85 \mathrm{a}$ \\
23 & $110.86 \mathrm{a}$ & $104.650 \mathrm{a}$ & $81.080 \mathrm{~b}$ & $83.18 \mathrm{c}$ \\
31 & 136.21 & $150.01 \mathrm{a}$ & $118.41 \mathrm{a}$ & $137.63 \mathrm{ab}$ \\
39 & 135.53 & $153.17 \mathrm{a}$ & $121.000 \mathrm{a}$ & $110.65 \mathrm{bc}$ \\
\hline \hline
\end{tabular}

a: Average of four replications; $100 \%, 50 \%, 33.3 \%$ and $0 \%$ refer to different leachate concentrations. Means with same letter in the same column are not significantly different at the $5 \%$ level.

ns: not significant.

**: significant at $1 \%$ level.

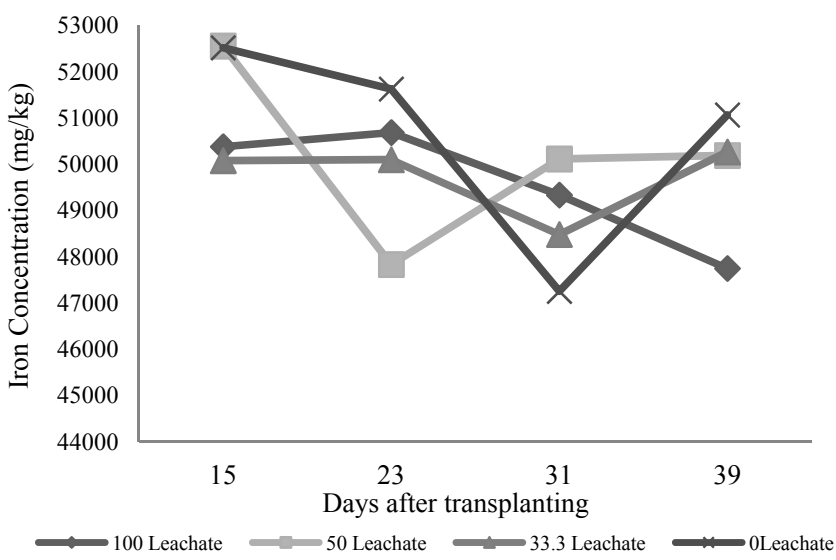

Fig. 2. Effect of different concentration leachates application on iron concentration in soil.

Thirty-nine days after transplanting, B. chinensis treated with $100 \%, 50 \%$ leachates showed increased in iron accumulation by $22.5 \%$ and $38.4 \%$ respectively, comparison to control $B$. chinensis. This was probably due to leachate addition has increased bioavailable iron in soil, but not in large amount as indicated by soil iron concentration not increased followed by leachate treatment. B. chinensis treated with $33.3 \%$ leachate showed no significant different in iron accumulation, but increased in dry matter yield by $95.7 \%$. This showed that diluted $33.3 \%$ leachate would provide a good nutrient supplement to plant.

There was a significant difference at $1 \%$ level on days after transplanting for $B$. chinensis iron uptake for each treatment except at $100 \%$ leachate treatment (Table V). The leachate concentration was decreased the degree of iron uptake variation among days after transplanting. Fifteen days after transplanting the highest iron uptake for $B$. chinensis was revealed (Table V), it maybe accrued due to poor growth rate and high available iron release from soil system. Twenty-three days after transplanting of $B$. chinensis the lowest iron uptake was observed (Table V) due to dilution effect of rapid increasing biomass. 
Overall results showed that accumulation of iron by $B$. chinensis depended on the stage of developments, growth of $B$. chinensis and leachate treatments. There was no injury and appearance of metal toxicity symptom during the growth of $B$. chinensis. Long or short term monitoring of plant could be a better indicator of some amount of metal pollution on soil than total soil metal content analysis. To avoid misleading of data interpretation, focusing on plant metal accumulation due to metal pollution, matured plant part are subjected to be sampled (Fig. 3).

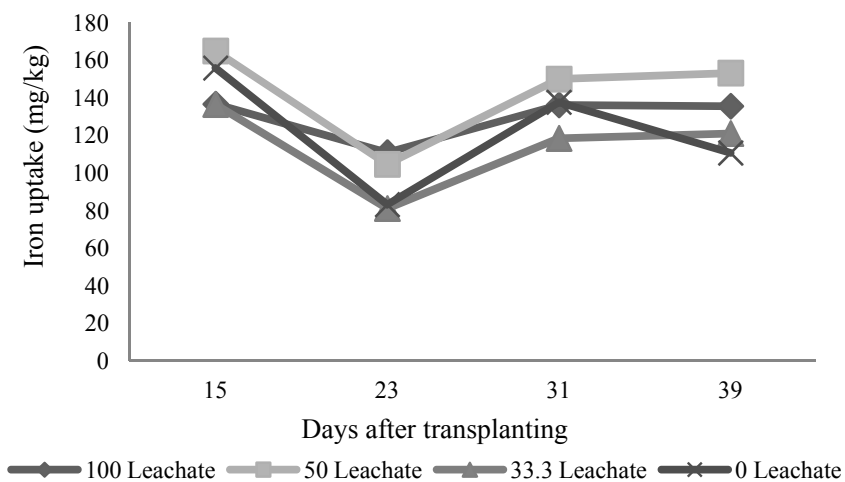

Fig. 3. Effect of different concentration leachates application on $B$. chinensis iron uptake

\section{CONCLUSIONS}

The application of landfill leachate increased the dry matter yield of B. chinensis $59.2 \%$ - $95.7 \%$ compared to control irrigated water. This result proves the previous reports of positive effect of leachate treatment on this species and plant growth [17], [18].

A single application of low iron concentration landfill leachate did not increase soil total iron content due total iron content in leachate added to soil was low as compared variation of background total iron in soil used as growth medium.

The accumulation of iron by $B$. chinensis depends on the stage of developments, growths of $B$. chinensis and leachate treatment. Brassica chinensis treated with landfill leachate have accumulated iron $22.5 \%-38.4 \%$ higher than control during their mature stage. Matured $B$. chinensis served as a better indicator of small amount of iron contamination on soil than total soil iron content analysis. This result is in agreement with [18].

Other factors should be considered beside total soil iron content in order to predict the plant iron uptake.

\section{REFERENCES:}

[1] P. Modak, "Municipal solid waste management:Turning waste into resources," Shanghai Manual - A Guide for Sustainable Urban Development in the 21st Century, pp. 2-5, 2011.

[2] N. Vanderlaan, L. Smith, and L. Watkins, "Trends In Fracking Groundwater Contamination Litigation," Law360, New York, pp. 1-4, 2012.

[3] S. Mahimairaj, N. S. Bolan, D. C. Adriano, and B. Robinson, "Arsenic contamination and its risk management in complex environmental settings," Advances in Agronomy, vol. 86, pp. 50-63, 2005 .
[4] M. Shoeybi and J. L. Salvacion, "Landfill leachate degradation in tropical maritime climate; an experimental laboratory scale study," in International Conference on Environment Science and Engieering, Singapoore, pp.103-108, 2012.

[5] M. Shaikh, N. Moleele, G. I. E. Ekosse, O. Totolo, and J. Atlhopheng, "Soil heavy metal concentration patterns at two speed zones along the gaborone tlokweng border post highway, southeast Botswana," Journal applied science and environment, vol. 10, no. 2, pp. 135-143, 2006.

[6] C. Xi , X. Xia, Y. Zhao, and P. Zhang, "Heavy metal concentrations in roadside soils and correlation with urban traffic in Beijing, China," Journal of hazardous materials, pp. 1-3, 2010.

[7] V. T. Sanyaolu, A. A. Sanyaolu, and E. Fadele, "Spatial variation in heavy metal concentration in an arable soil along a major highway in Ikorodu-Lagos, Nigeria," Journal of Soil Science and Environmental Management, vol. 3, no. 10, pp. 231-236, Oct. 2012.

[8] P. A. de P. Pereira, W. A. Lopes, L. S. Carvalho, G. O. d. Rocha, N. d. C. Bahia, J. Loyola, S. L. Quiterio, V. Escaleira, G. Arbilla, and J. B. d. Andrade, "Atmospheric concentrations and dry deposition fluxes of particulate trace metals in Salvador, Bahia, Brazil," Atmospheric Environment, vol. 41, pp. 7837-7850, 2007.

[9] H. M. Faragallah, A. I. Askar, M. A. Okbah, and H. M. Moustafa, "Physico-chemical characteristics of the open Mediterranean sea water far about $60 \mathrm{Km}$ from Damietta harbor, Egypt," Journal of Ecology and The Natural Environment, vol. 1, no. 5, pp. 106-119, August 2009.

[10] J. A. Cooke and M. S. Johnson, "Ecological restoration of land with particular reference to the mining of metals and industrial minerals: A review of theory and practice," Environmental Reviews Journal, vol. 10, pp. 41-71, 2002.

[11] W. J. Lin, T. F. Xiao , Z. Q. Ao, J. Xing, H. C. Ma, and T. X. Hu, "Limiting factors of waste land revegetation in indigenous zinc smelting areas of western Guizhou," The Journal of Applied Ecology, vol. 18, no. 3, pp. 631-635, May 2007.

[12] J. Kowalska, E. Stryjewska, G. Bystrzejewska-Piotrowska, K. Lewandowski, M. Tobiasz, J. Pałdyna, and J. Golimowski, "Studies of Plants Useful in the Re-Cultivation of Heavy Metals-Contaminated Wasteland a New Hyper accumulator of Barium?," Poland Journal of Environment Study, vol. 21, no. 2, pp. 401-405, 2012.

[13] LaMotte. LaMOTTE COMPANY. (2 Dec 2002). [Online]. Available: http://lamotte.com/images/pdfs/instructions/1067.pdf.

[14] K. P. Baiyeri and A. Tenkouano, "Manure placement influenced growth and dry matter yield of a plantain hybrid," African Crop Science Conference Proceedings, vol. 8, pp. 385-390, 2007.

[15] I. A. Robert and K. D. Jack, "Atomic absorption and flame photometry: techniques and uses in soil, plant and water analysis," in Instrumental Methods for Analysis of Soils and Plant Tissue, L. M. Walsh, Ed 1., Madison, Soil Science society of America, Inc, pp. 2829,1971 .

[16] B. Słomczyńska and T. Słomczyński, Polish Journal of Environmental Studies, vol. 13, no. 6, pp. 627-637, 2004.

[17] N. Wilson, "Land treatment of landfill leachate," Minnesota Pollution Control Agency, Minnesota, 2011.

[18] M. H. Wong and C. K. Leung, "Landfill leachate as irrigation water for tree and vegetable crops," Waste Management \& Research, vol. 7, no. 4, pp. 311-323, December 1989.

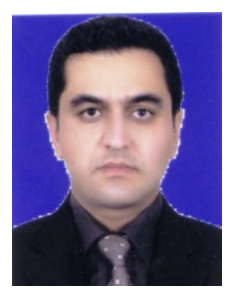

Reza Farzinebrahimi was born in Kerman, Iran in 1973, graduated in 1995 from Islamic Azad University in Iran-Kerman in Bachelor of horticulture. In 2009, he continued his study in plant biotechnology in University of Malaya in Kuala Lumpur-Malaysia and graduated in Master of Science with major of plant tissue culture.

Mr. Farzinebrahimi has been worked as a head of Complex of Laboratories and Workshops in Islamic Azad University, Sirjan branch-Iran from 2000 to 2006. He awarded a fellowship from University Putra Malaysia, Serdang-Malaysia from 2006 to 2007, Bright Sparks grant in 2013 from university of Malaya-malaysia. He worked as research assistant in University of Malaya-Malaysia (Faculty of Science, ISB, Second floor) from 2009 to 2013. He has been published more than six papers in ISI and Scopus journals. 